ATTHULAB:

Islamic Religion Teaching \& Learning Journal

Volume 4 Nomor 2 Tahun 2019

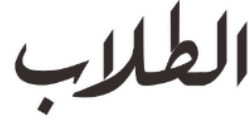

http://journal.uinsgd.ac.id./index.php/atthulab/

\title{
Pendidikan akhlak Ibnu Miskawaih dan Imam al-Ghazali dalam pendidikan karakter di Indonesia
}

\author{
Ahmad Busroli \\ Pascasarjana Universitas Islam Negeri Imam Bonjol Padang \\ Jalan Jend. Sudirman Padang Pasir Kota Padang Sumatera Barat 25153 Indonesia \\ Email: ahmadbusroli19@gmail.com
}

\begin{abstract}
Ibn Miskawaih is known as the first Muslim intellectual in the field of moral philosophy. He is known as a historian, philosopher, doctor, poet, and linguist. As with Ibn Miskawaih, Imam al-Ghazali is a person who loves science, a person who likes to find the truth. Imam al-Ghazali studied various branches of science such as religious knowledge, ushul science, mantiq, rhetoric, logic, kalam science, and philosophy. By his advantages that he had made, Imam Ghazali was not satisfied, until he became a Sufi. Therefore, the Thought of Ibn Miskawaih and Imam al-Ghazali should be said as multi-scientific Muslim figures. By his knowledge that he had, there can be no doubt that the thoughts of Ibn Miskawaih and Imam al-Ghazali can provide changes in science, especially in the field of morality. The religious, critical, and humanist thoughts of Ibn Miskawaih and Imam al-Ghazali united abstract thinking with very logical practices and it showed coherence and consistency that it could be used as references for the development of moral education, especially in Character Education in Indonesia, especially in this era where humans have not been able to maintain moral values in aspects of life and continue to experience moral decadence.
\end{abstract}

Keywords:

Miskawaih; al-Ghazali; moral; character building

Abstrak: Ibn Miskawaih dikenal sebagai intelektual Muslim pertama di bidang filsafat moral. Ia dikenal sebagai sejarawan, filsuf, dokter, penyair, dan ahli bahasa. Seperti halnya Ibn Miskawaih, Imam al-Ghazali adalah orang yang mencintai sains, orang yang suka menemukan kebenaran. Imam al-Ghazali mempelajari berbagai cabang ilmu pengetahuan seperti ilmu agama, ilmu ushul, mantiq, retorika, logika, ilmu kalam, dan filsafat. Dengan kelebihannya yang dia buat, Imam Ghazali tidak puas, sampai dia menjadi seorang Sufi. Oleh karena itu, Pemikiran Ibn Miskawaih dan Imam al-Ghazali harus dikatakan sebagai tokoh Muslim multi-ilmiah. Dengan pengetahuan yang ia miliki, tidak ada keraguan bahwa pemikiran Ibn Miskawaih dan Imam alGhazali dapat memberikan perubahan dalam sains, terutama di bidang moralitas. Pemikiran agama, kritis, dan humanis Ibn Miskawaih dan Imam al-Ghazali menyatukan pemikiran abstrak dengan praktik yang sangat logis dan menunjukkan koherensi dan konsistensi bahwa itu dapat digunakan sebagai referensi untuk pengembangan pendidikan moral, terutama dalam Pendidikan Karakter di Indonesia, terutama di era ini di mana manusia belum mampu mempertahankan nilai-nilai moral dalam aspek kehidupan dan terus mengalami dekadensi moral.

Kata Kunci:

Miskawaih; al-Ghazali; moral; pendidikan karakter

DOI: http:/ / dx.doi.org/10.15575/ath.v4i2.5583

Received: 08, 2019. Accepted: 10, 2019. Published: 11, 2019

\section{PENDAHULUAN}

Pendidikan pada dasarnya adalah usaha sadar untuk membentuk manusia yang beriman dan bertaqwa kepada Tuhan yang maha esa, berbudi pekerti luhur, memiliki pengetahuan dan keterampilan, memiliki kepribadian yang mantap dan mandiri serta memiliki rasa tanggung jawab kemasyarakatan dan kebangsaan. Sedangkan pendidikan 
dalam arti luas berarti suatu proses untuk mengembangkan semua aspek kepribadian manusia yang mencakup pengetahuannya, nilai, sikapnya, dan keterampilanya (Burhanuddin, 2002: 10).

Pendidikan Islam bertujuan menjadikan peserta didik memiliki akhlak yang mulia. Pendidikan akhlak atau yang lebih dikenal dengan karakter adalah serangkain prinsip dasar moral dan keutamaan sikap serta watak atau tabiat yang harus dimiliki dan dijadikan kebiasaan oleh anak sejak masa pemula hingga menjadi mukallaf, yakni siap untuk memengarungi lautan kehidupan. Imam Al-Ghazali menekankan bahwa akhlak adalah sifat yang tertanam dalam jiwa manusia, yang dapat dinilai baik atau buruk dengan menggunakan ukuran ilmu pengetahuan dan norma agama (Dindin jamaluddin, 2013: 16). Pendidikan akhlak ialah membimbing anak agar menjadi manusia muslim sejati, beriman teguh, beramal saleh, berakhlak mulia serta berguna bagi masyarakat, agama dan bangsa. Maka tujuan pendidikan akhlak diartikan sebagai rumusan kualisifikasi pengetahuan kemampuan sikap yang diharus dimiliki oleh peserta didik setelah menyelesaikan suatu program pembelajaran.

Pendidikan bernafaskan Islam bukanlah sekedar pembentukan manusia semata, tetapi juga berlandaskan Islam yang mencakup agama, akal, kecerdasan jiwa, yaitu pembentukan manusia seutuhnya dalam rangka membentuk manusia yang berakhlak mulia sebagai tujuan utama pengutusan Nabi Muhammad SAW dalam rangka melaksanakan perintah Allah SWT serta mengenal agama secara teori dan praktis. Islam sebagai gerakan pembaharuan akhlak dan sosial melalui peran Nabi Muhammad SAW sebagai pembawa risalah, secara tegas telah menyatakan bahwa tugas utamanya adalah sebagai penyempurna akhlak manusia.

Perkembangan zaman sekarang membuat manusia belum mampu mempertahankan nilai-nilai akhlak yang telah ada pada dirinya. Kemajuan yang berkembang pesat dibidang science dan teknologi harus selalu diimbangi antara kebebasan berfikir dan kesadaran jiwa dengan adanya rasa tanggung jawab kepada Allah SWT. Kemajuan teknologi dan ilmu pengetahuan yang berkembang secara menyeluruh menjadikan sebuah era globalisasi yang penuh dengan kecanggihan diberbagai sektor. Dampaknya segera terasa dalam berbagai bidang kehidupan manusia baik ekonomi, politik, perdagangan, gaya hidup, bahkan agama. Arus globalisasi tidak hanya berlangsung pada aspek kehidupan yang bersifat material, akan tetapi berlanjut pada aspek non material seperti akhlak. Akibat dari pengaruh negatif arus budaya global, dapat melahirkan umat manusia yang tuna karakter (Maragustam, 2014: 2).

Arus globalisasi bukanlah kawan maupun lawan bagi pendidikan Islam, melainkan sebagai dinamisator bagi mesin yang namanya pendidikan Islam. Globalisasi langsung ataupun tidak dapat membawa paradoks bagi praktik pendidikan Islam, seperti terjadinya kontras moralitas (das solen) dengan realitas di lapangan (das sain) (Amin Abdullah dan Rahmat, 2004: 10-11). Rusaknya karakter pada umumnya dikarenakan pendangkalan keimanan yang dirusak oleh umat Islam sendiri yang mengakibatkan semakin dalamnya jurang pemisah antara ideal dan realita, moral dan tindakan, dan antara landasan teori dan aktivitas praktis. Pola hidup materealistis, sikap individualitas, konsumtif, dan kesenjangan sosial yang telah menjadi darah daging bagi sebagian umat Islam merupakan contoh konkrit dari dangkalnya keimanan seseorang kepada Allah SWT, tuhan satu-satunya yang wajib disembah dan diagungkan. Gaya hidup yang semakin memperlihatkan lemahnya simpati dalam diri, seperti gotongroyong serta tolong menolong, bahkan meningkatnya tindak kejahatan dan kriminalitas. Persolan tersebut seperti tawuran antar pelajar, penggunaan narkoba, meminum 
minuman keras, pergaulan bebas, LGBT dan budaya Korupsi Kolusi Nepotisme (KKN) yang menunjukkan angka peningkatan (Mochamad Iskarim, 2016: 3-4)

Setelah diamati ternyata masih banyak tindakan yang dapat merusak akhlak dan merupakan suatu tanda-tanda karakter bangsa mengalami jurang kehancuran, Pertama; meningkatnya kekerasan di kalangan remaja, kedua penggunaan bahasa dan kata-kata yagn buruk. Tiga; pengaruh peer-group yang kuat dalam kekerasan. Keempat; meningkatnya perilaku merusak diri. Kelima; semakin kaburnya pedoman moral baik dan buruk. Keenam; menurunnya etos kerja. Ketujuh; semakin rendahnya rasa hormat kepada orang tua dan guru. Kedelapan; rendahnya rasa tanggung jawab individu dan warga negara. Kesembilan; membudayanya ketidak jujuran, dan kesepuluh; adanya rasa saling mencurigai dan kebencian di antara sesama (Masnur Muslich, 2011: 35).

Dalam pendidikan akhlak aktualisasi nilai-nilai Islam perlu dipandang sebagai suatu persoalan yang penting dalam usaha penanaman ideologis Islam sebagai pandangan hidup. Namun demikian dalam usaha aktualisasi nilai-nilai moral Islam memerlukan proses yang lama, agar penanaman tersebut bukan sekedar dalam formalitas namun telah masuk dalam dataran praktis. Untuk itu, perlu kiranya menghubungkan faktor penting kebiasaan, memperhatikan potensi anak didik, juga memerlukan bentuk-bentuk dan metode-metode yang sesuai dengan kebutuhan anak didik (Abuddin Nata, 2000: 7).

Beberapa nilai atau hikmah yang dapat diraih berdasarkan ajara-ajaran amaliah Islam (akhlaq) antara lain: Al-amanah (setia, jujur, dapat dipercaya), al Sidqu (benar, jujur), al-Adl (adil), al-Afwu (pemaaf), al-Alifah (disenangi), al-Wafa (menepati janji), alHaya (malu), ar-Rifqu (lemah lembut), dan aniisatun (bermuka manis) (Abdullah Nashih Ulwan, 15-18).

Dengan mengkaji pendidikan akhlak Ibnu Maskawaih dan Imam Al-Ghazali, proses pendidikan dapat berlangsung dengan baik dan kemungkinan peserta didik tidak akan melakukan perbuatan buruk seperti kejahatan, kekerasan dan perilaku menyimpang lainnya. Sebab, apabila hal kecil semacam ini merasuk ke dalam jiwa dan melekat masa kecilnya, maka untuk mengubahnya kembali akan mengalami kesulitan, sehingga orang tua pun akan mengalami kesulitan menyikapi hal tersebut.

Ibn Miskawaih menjelaskan akhlak merupakan suatu keadaan jiwa. Keadaan ini menyebabkan jiwa bertindak tanpa berpikir atau dipertimbangkan secara mendalam. Keadaan tersebut ada dua jenis, yaitu pertama, alamiah dan bertolak dari watak. Kedua, tercipta melalui kebiasaan dan latihan. Pada mulanya keadaan ini terjadi karena dipertimbangkan dan dipemikiran, namun kemudian melalui praktik terus-menerus akan menjadi karakter" (Ibnu Miskawaih, 1994: 56). Sementara menjelaskan Imam Al Gazali akhlak adalah sebuah bentuk ungkapan yang tertanam dalam jiwa yang menimbulkan perbuatan-perbuatan yang gampang dan mudah tanpa memerlukan pemikiran dan pertimbangan (Muhammad al-Baqir, 2015: 28)

Ibnu Miskawaih menetapkan kemungkinan manusia mengalami perubahanperubahan khuluq, dan dari segi inilah maka diperlukan adanya aturan-aturan syariat, nasihat-nasihat, dan berbagai macam ajaran tentang adab sopan santun. Adanya itu semua memungkinkan manusia dengan akalnya mampu membedakan mana yang seharusnya dilakukan dan mana yang tidak. Dari situlah, Miskawaih memandang akan pentingnya pendidikan dan lingkungan dalam membina akhlak (A. Mustafa, 2007: 177).

Dengan pengertian pendidikan akhlak yang dikemukakan oleh Ibn Miskawaih dan Imam Al-Ghazali menunjukkan bahwa keduanya adalah tokoh Muslim yang representatif di bidang akhlak (etika), pemikiran pendidikan akhlak kedua tokoh tersebut dapat dihidupkan kembali ke zaman modern ini, guna memfilter arus 
globalisasi dan ilmu pengetahuan teknologi informasi yang terus berkembang. Sehingga terciptanya manusia yang kritis, cerdas, dan berakhlak mulia di tengah-tengah laju perkembangan zaman.

Pembahasan ini untuk melihat relevansi pemikiran kedua tokoh tersebut dengan pendidikan karakter. Karakter dapat dimaknai sebagai nilai dasar yang membangun pribadi seseorang, terbentuk baik karena pengaruh hereditas maupun pengaruh lingkungan, yang membedakannya dengan orang lain, serta diwujudkan dalam sikap dan perilakunya dalam kehidupan sehari-hari. Pendidikan karakter telah menjadi sebuah pergerakan pendidikan yang mendukung pengembangan sosial, pengembangan emosional dan pengembangan etika para peserta didik. Pendidikan karakter merupakan upaya proaktif yang dilakukan oleh elemen sekolah, dan pemerintah untuk membantu peserta didik mengembangkan inti pokok dari nilai-nilai etik dan kinerja.

Oleh sebab itu, pendidikan akhlak mendorong jiwa seorang mukmin untuk mencintai syari'ah agamanya, menanamkan nilai syariah dalam jiwa mereka, membangun pemahaman tentang figuritas keteladanan dalam akhlak dan memotivasi berperilaku mereka dengan sifat-sifat yang terpuji dalam perkembangan akhlak. Dengan kata lain, esensi dari pendidikan akhlak adalah melahirkan manusia yang berpribadi muslim yang taat terhadap hukum dan ketetapan syari'ah Islam. Sedangkan pendidikan karakter sebagai upaya sadar yang sungguh-sungguh dilakukan oleh pendidik untuk mengajarkan nilai-nilai kepada para peserta didik agar memiliki karakter seperti kepedulian, kejujuran, kerajinan, keuletan dan ketabahan (fortitude), tanggung jawab, menghargai diri sendiri dan orang lain.

Hal yang menarik dengan dilakukannya kajian ini berkaitan dengan pemikiran Ibnu Miskawaih dan Imam al-Ghazali yang membahas tentang akhlak. Karena pemikiran tentang akhlak tersebut berdasarkan hasil pengamatan empiris yang ia lakukan dan ditambah dengan adanya mujahadah, riyadhah, menyibukkan diri dengan penyucian jiwa. Hal ini membuat pemikirannya masih banyak yang relevan untuk diteliti, diaktualisasikan dan diimplementsikan secara komprehensif dalam konteks kekinian. Jika memang relevan apakah pemikiran tersebut masih relevan dengan pendidikan karakter di Indonesia? Tulisan ini akan berupaya menjawab pertanyaan tersebut dengan baik.

Pokok-pokok Pemikiran Pendidikan Akhlak Ibnu Miskawaih dari kitab Tahzibul Akhlak terkait dengan Pendidikan Akhlak, di antaranya: 1) Hakikat Manusia; 2) Tujuan Pendidikan Akhlak; 3) Materi Pendidikan Akhlak; 4) Metode Pendidikan Akhlak yang terdiri dari a) Metode Alami, b) Metode bimbingan, c) Metode Pembiasaan dan d) Metode Hukuman, Hardikan, dan Pukulan yang Ringan; 5) Pendidik dan Peserta Didik; 6) Lingkungan Pendidikan Akhlak. Pokok-pokok pemikiran pendidikan akhlak menurut Imam Al-Ghazali di antaranya: 1) Hakikat Manusia; 2) Tujuan Pendidikan Akhlak; 3) Materi Pendidikan Akhlak yang terdiri dari a) Ilmu-ilmu yang fardhu 'ain mempelajarinya, b) Ilmu-ilmu yang Fardhu Kifayah untuk memperlajarinya; 4) Metode Pendidikan Akhlak; 5) Pendidik dan peserta didik; 6) Lingkungan Pendidikan Akhlak, a) Keluarga, b) Sekolah/madrasah, dan c) Masyarakat.

\section{METODE PENELITIAN}

Penelitian ini termasuk ke dalam penelitian kepustakaan (library research), yaitu dengan mengunakan pendekatan deskriptif analisis. Pendekatan berikutnya yang digunakan oleh peneliti adalah pendekatan filosofis. Sumber data dalam penelitian ini meliputi, sumber data primer berupa Kitab Ibnu Miskawaih, Tahdzib al-Akhlak, (Beirut : Darul al- 
Kutub al-Ilmiah, $1329 \mathrm{H}$ dan terjemahannya Ibnu Miskawaih, Tahdzib al-Akhlak, Ter. Helmi Hidayat, Menuju Kesempurnaan Akhlak, (Bandung: Mizan, 1994) dan Kitab AlGhazali, Ihya Ulum ad-Din, (Beirut: Cet. III Daru al-Fikri, 1411 H), dan terjemahannya AlGhazali, Ihya Ulmu al-Din, Ter. Muhamamd Al-Baqir, Mengobati Penyakit Hati Membentuk Akhlak Mulia, ( Bandung: Mizan, 2015). Sumber data sekunder berupa buku-buku atau bahan bacaan yang berkaitan dengan penelitian ini. Teknik pengumpulan data dengan menggunakan tiga tahapan yaitu tahap orientasi, ekspolorasi, dan studi terfokus. Sedangkan metode analisis data yang digunakan adalah analisis kualitatif. Teknis analisis data yang digunakan adalah teknik analisis isi (content analisys) yaitu penelitian yang dilakukan terhadap informasi yang di dokumentasikan dalam rekaman, gambar, suara, maupun tulisan.

\section{HASIL PENLITIAN DAN PEMBAHASAN}

Meskipun Ibnu Miskawaih hidup di abad ke-10, tetapi pemikirannya tentang pendidikan akhlak tampaknya tetap aktual dan relevan untuk penerapan pendidikan karakter dalam konteks kekinian, termasuk di Indonesia. Bahkan pemikiran yang pernah beliau kemukakan dapat menjadi inspirasi untuk umat Islam dewasa ini dalam membenahi dan meningkatkan pendidikan karakter Indonesia.

\section{Relevansi Hakikat Manusia}

Ibnu Miskawaih memandang manusia adalah makhluk yang memiliki keistimewaan karena dalam hakikatnya manusia memiliki daya berpikir. Berdasarkan daya berpikir tersebut, manusia dapat membedakan antara yang benar dan salah, serta yang baik dan buruk. Dan manusia yang paling sempurna ialah mereka yang paling benar cara berpikirnya serta yang paling mulia usaha dan perbuatannya. Usaha untuk mewujudkan kebaikan merupakan indikator dari tingkat kesempurnaan dan tujuan dari pernciptaan manusia itu sendiri (Jalaluddin dan Usman Sa'id, 1994: 135).

Manusia sebagai makhluk makhluk yang memiliki keistimewaan karena memiliki daya pikir dan macam-macam daya. Menurut Ibnu Miskawaih (Helmi Hidayat, 1994: 43-44), didalam diri jiwa manusia terdapat tiga daya yaitu:

a. Daya bernafsu (an-nafs al bahimiyyat) sebagai daya terendah.

b. Daya berani (an-nafs as-sabu'iyyat) sebagai daya pertengahan.

c. Daya berpikir (an-nafs an-nathiqat) sebagai daya tertinggi.

Ketiga daya ini merupakan daya manusia yang asal kejadiannya berbeda. Unsur rohani berupa bernafsu (An-Nafs Al-Bahimmiyyat) dan berani (an-Nafs as-Sabu'iyyat) berasal dari unsur materi sedangkan berpikir (an-Nathiqat) berasal dari ruh Tuhan karena itu Ibnu Miskawaih berpendapat bahwa kedua an-nafs yang berasal dari materi akan hancur bersama hancurnya badan dan an-Nafs an-Nathiqat tidak akan mengalami kehancuran. Dalam hal ini, Ibnu Miskawaih mengatakan bahwa hubungan jiwa alBahimmiyyat/ as-Syahwiyyat (bernafsu) dan jiwa as-Sabu'iyyat/ al-Ghadabiyyat (berani) dengan jasad pada hakikatnya sama dengan hubungan saling mempengaruhi.

Sedangkan Imam Al-Ghazali memandang bahwa manusia terdiri dari tiga unsur yaitu unsur jiwa, jasmani dan rohani (Al-Ghazali, 1964: 16). Selain itu Imam Al-Ghazali memandang manusia memiliki empat potensi yaitu, kemampuan dasar atau kekuatan pengetahuan, kekuatan emosi (ghadhab), kekuatan ambisi (syahwat), dan kekuatan yang menyeimbangkan antara ketiga potensi tersebut. Adapun yang menjadi hakikatnya adalah kekuatan pengetahuan (Muhammad Al-Baqir, 2014: 30). Pandangan kedua tokoh ini selanjutnya akan mempengaruhi seluruh komponen pendidikan lainnya, termasuk dalam perumusan tujuan pendidikan. Dengan demikian daya berfikir dan kekuatan pengetahuan akan menjadi naik dan sempurna, apabila hal itu mampu 
memudahkannya untuk membedakan antara ketulusan dan kebohongan dalam hal ucapan, antara hak dan yang batil dalam hal kepercayaan, antara yang baik dan buruk dalam hal perbuatan.

Pandangan kedua tokoh tersebut tampaknya memiliki relevansi dengan pandangan pendidikan karakter yang berkembang di Indonesia. Mengenai konsep manusia dalam pandangan pendidikan karakter yang diterapkan di Indonesia dapat dilihat Permendikbud No 20 Tahun 2018 pasal 2 tentang Penguatan Pendidikan Karakter (PPK) yaitu PPK dilaksanakan dengan menerapkan nilai-nilai Pancasila dalam pendidikan karakter terutama meiiputi nilai-nilai religius, jujur, toleran, disiplin, bekerja keras, kreatif mandiri, demokratis, rasa ingin tahu, semangat kebangsaan, cinta tanah air, menghargai prestasi, komunikatif, cinta damai, gemar membaca, peduli lingkungan, peduli sosial, dan bertanggung jawab.

Dari kedelapan belas karakter di atas, secara eksplisit memang tidak sama persis dengan pandangan Ibnu Miskawaih dan Imam al-Ghazali tentang hakikat manusia yang ideal. Tetapi secara substansi tidak terlepas dari yang dimaksud dan tidak ada perbedaan yang bertolak belakang. Untuk lebih jelasnya relevensi tersebut dapat dilihat sebagai berikut: Pertama, Ibnu Miskawaih dan Imam Al-Ghazali menyebutkan bahwa manusia ialah makhluk yang memiliki daya berpikir dan kekuatan pengetahuan. Pandangan ini relevan dengan konsep manusia dalam Permendikbud No 20 Tahun 2018 pasal 2, yang menyebutkan bahwa pendidikan hendaknya menjadikan manusia yang memiliki karakter rasa ingin tahu, disiplin, kreatif, dan bekerja keras. Kriteria rasa ingin tahu, disiplin, kreatif dan bekerja keras menandakan bahwa manusia sebagai makhluk yang berpikir sehingga ia membutuhkan dan berkeinginan untuk menguasai ilmu yang ada, dengan rasa ingin tahu, disiplin dan kreatif sehingga meningkatkan potensi dari daya berpikir dan kekuatan pengetahuan.

Kedua, Ibnu Miskawaih dan Imam Al-Ghazali berpendapat bahwa kepribadian manusia berasal dari jiwa. Sementara dalam Permendikbud No 20 Tahun 2018 pasal 2 memang tidak disebutkan secara tertulis bahwa manusia memiliki jiwa. Tetapi dengan adanya kriteria religius menunjukkan bahwa Permendikbud tersebut mengakui adanya unsur jiwa bagi manusia sebab persoalan jiwa sudah terkandung iman dan takwa sebagai penopang untuk memunculkan jiwa yang sehat. Kriteria religius juga menunjukkan bahwa memiliki dimensi yang urgen, yaitu dimensi rohani. Dalam dimensi rohani tersebut terdapat fitrah beragama dan manusia seharusnya hidup dan berkembang sesuai dengan fitrah tersebut. Adapun indikator kriteria religius menurut Al-Ghazali ialah pertama, menjalankan perintah Allah. Kedua, menjauhi laranganlarangan Allah. Ketiga, berprilaku sesuai dengan hukum agama. Keempat, tidak melakukan perbuatan yang melanggar hukum-hukum agama. Dengan demikian, dapat diketahui bahwa kriteria religius ini merupakan salah satu bagian dari pendidikan karakter yang akan membantu dalam penanaman nilai-nilai karakter yang ada di dalam pendidikan karakter, sesuai dengan peraturan yang ada di Indonesia.

Kriteria rasa ingin tahu, gemar membaca, kreatif, bekerja keras, dan mandiri mengisyaratkan bahwa Permendikbud No 20 Tahun 2018 pasal 2 memandang manusia memiliki potensi berpikir dan peningkatan pengetahuan. Adapun dimensi jiwa (nafs) tampaknya perlu dikembangkan dengan adanya kriteria jujur, toleransi, disiplin, bekerja keras, kreatif, mandiri, gemar membaca dan rasa ingin tahu. Al-Ghazali menguraikan kriteria-kriteria tersebut ke dalam indikator-indikator. Indikator dari rasa ingin tahu ialah tidak pernah merasa puas, suka bertanya, suka membaca berita dari koran, dan sumber berita lainnya, suka mendengarkan berita-berita, dan suka membaca Al-Qur'an, hadits, serta kitab-kitab sebagai sumber pengetahuan. Indikator dari jujur 
ialah mengatakan yang sebenarnya, mengatakan sesuai dengan yang dilakukan, mengerjakan tugas-tugas sesuai dengan ketentuan yang ada, tidak mengambil yang bukan haknya, tidak menyontek dalam mengerjakan ujian dan tugas dari sekolah. Indikator dari bekerja keras ialah selalu bersungguh-sungguh dalam melakukan sesuatu pekerjaan untuk mencapai yang diinginkan. Kemudian indikator dari kreatif yaitu manusia harus memiliki kemampuan untuk memahami keadaan, dalam menginterpretasikan pengalaman dan memecahkan suatu masalah dengan cara yang baru atau menciptakan sesuatu hal baru yang bermanfaat. Indikator kriteria mandiri didasar kepada suatu konsep bahwa manusia ialah makhluk individual yang mesti memiliki pegangan hidup secara istiqamah, mempunyai inisiatif yang mampu mengatasi hambatan atau masalah.

Ketiga, Ibnu Miskawaih memandang manusia sebagai khalifah Allah fi al-Ardh. Pandangan ini juga relevan dengan pandangan Permendikbud No 20 Tahun 2018 pasal 2 tentang manusia, yang didalam tujuan tersebut disebutkan bahwa peserta didik diharapkan mampu menjadi manusia yang bertanggung jawab. Kriteria bertanggung jawab tentu erat kaitannya dengan fungsi manusia sebagai khalifah Allah fi al-Ardh. Khalifah Allah fi al-Ardh hakikatnya merupakan amanah yang diberikan kepada manusia. Untuk menjalankan amanah tersebut tentunya dibutuhkan manusia yang bertanggung jawab. Sedangkan dalam pandangan Al-Ghazali, indicator kriteria bertanggung jawab yaitu tidak menyia-nyiakan amanah, melaksanakan kewajiban, dan terpercaya.

Keempat, Ibnu Miskawaih dan Al-Ghazali memandang manusia sebagai makhluk sosial. Konsep ini juga relevan dengan konsep manusia dalam Permendikbud No 20 Tahun 2018 pasal 2 yang bertujuan menghasilkan peserta didik mandiri, demokrasi, toleransi, semangat kebangsaan, cinta tanah air, menghargai prestasi, komunikatif, cinta damai, peduli lingkungan dan peduli sosial. Manusia mandiri menandakan bahwa manusia adalah makhluk individu, bukan berarti tidak membutuhkan bantuan orang lain tetapi ada usaha yang dilakukan terlebih dahulu sebelum menerima bantuan dari orang lain. Sedangkan kriteria manusia yang demokrasi, toleransi, semangat kebangsaan, cinta tanah air, menghargai prestasi, komunikatif, cinta damai, peduli lingkungan dan peduli sosial menunjukkan manusia sebagai makhluk sosial. Makhluk sosial ditandai dengan adanya hidup saling ketergantungan, bantuan, dan kerjasama terhadap orang lain, sebab manusia tidak dapat melangsungkan kehidupannya jika dilakukan secara sendiri.

\section{Relevansi Tujuan Pendidikan}

Adanya relevansi konsep manusia Ibnu Miskawaih dan Al-Ghazali dengan pandangan Permendikbud No 20 Tahun 2018 pasal 2, tentunya memiliki relevansi juga dengan tujuan pendidikan. Pertama, Ibnu Miskawaih memandang bahwa dari segi struktur kepribadiannya pendidikan bertujuan untuk terwujudnya sikap bathin yang mampu mendorong secara spontan untuk melahirkan semua perbuatan yang bernilai baik, sehingga mencapai kesempiurnaan dan memperoleh kebahagiaan sejati. Sedangkan menurut Al-Ghazali, dari struktur kepribadiannya pendidikan bertujuan untuk mengembangkan unsur jiwa, jasmani, dan rohani secara optimal, sehingga seseorang melakukan tindakan terpuji secara fisik dan secara kejiwaan menikmati perbuatan tersebut untuk menjadi manusia sempurna. Sementara tujuan dari Permendikbud No 20 Tahun 2018 pasal 2 menghendaki agar manusia memiliki karakter religius, jujur, rasa ingin tahu, disiplin, kreatif dan bekerja keras.

Kedua, Ibnu Miskawaih dan Al-Ghazali berpendapat bahwa keberadaan manusia adalah sebagai makhluk sosial. Pendidikan bertujuan untuk mendidik manusia agar mampu hidup dalam bermasyarakat sehingga dengan kemampuan yang dimiliki dapat 
membawa perubahan pada lingkungan masyarakat yang memiliki pemikiran maju diera modern. Tujuan ini relevan dengan Permendikbud No 20 Tahun 2018 pasal 2 yang menginginkan agar pendidikan mampu mewujudkan manusia yang mandiri dan memiliki peran penting di tengah-tengah masyarakat berupa cinta tanah air, cinta damai, peduli lingkungan dan bertanggung jawab.

Ketiga, Ibnu Miskawaih dan Al-Ghazali berpendapat bahwa dari segi peran dan fungsi manusia sebagai hamba Allah dan khalifah Allah fi al-Ardh, pendidikan bertujuan untuk mendidik manusia agar mampu menjalankan aktivitasnya dengan baik dan sempurna dengan jalan mujahadah, pengontrolan diri, persahabatan, cinta, kebaikan, dan kebahagian agar tidak ada niat untuk merusak jagad raya ini. Tujuan ini juga relevan dengan tujuan dalam Permendikbud No 20 Tahun 2018 pasal 2 yang menginginkan pendidikan melahirkan manusia yang memiliki karakter religius dan bertanggung jawab untuk menjalankan amanah khalifah Allah fi al-Ardh.

Dengan demikian tampak jelas adanya relevansi pemikiran Ibnu Miskawaih dan Al-Ghazali tentang manusia dan tujuan pendidikan. Ibnu Miskawaih dan Al-Ghazali mengharapakan konsep tersebut tidak bersifat teoritis tetapi lebih kepada ranah praktis. Hal ini dibuktikan dengan konsep manusia yang bersifat menyeluruh yakni mencari kebahagiaan hidup manusia dalam artian seluas-luasnya.

Adapun dalam konteks keidonesiaan, relevansi yang dikemukakan tersebut sepertinya hanya bersifat teoritis, belum sampai pada tahap praktis sebagaimana yang diharapakan. Sebab manusia dipandang secara sebagian dari keseluruhan pemahaman tentang konsep manusia. Akibatnya tujuan pendidikan yang telah dirumuskan mengalami rintangan dalam pencapaian. Hal ini tentu terjadi ketidak sesuaian antara konsep dan realita.

Pelaksanaan pendidikan di Indonesia lebih menitik beratkan kepada aspek kognitif ditambah dengan rendahnya kualitas pendidik dalam menyajikan pembelajaran. Akibatnya, terjadi kecenderungan menurunnya akhlak dan moral yang menyebabkan lunturnya tanggung jawab dan kesetiakawanan sosial. Karena itu dapat disimpulkan bahwa pendidikan agama lebih menekankan pada akumulasi pengetahuan yang bersifat verbal dari pada penguasaan keterampilan, internalisasi nilai-nilai dan sikap, serta pembentukan kepribadian. Di samping itu kuantitas tampaknya lebih diutamakan dari pada kualitas. Persentase atau banyaknya lulusan lebih diutamakan daripada apa yang dikuasai atau bisa dilakukan oleh lulusan tersebut (Abidin Ibnu Rusn, 1998: 124-126).

Selain itu, pendidikan Indonesia dewasa ini mendapatkan sorotan tajam dari sebagian masyarakat terutama dalam pelaksanaan pendidikan di sekolah-sekolah sebagai lembaga formal. Hal ini didasari dari fenomena-fenomena sosial yang terjadi berupa degradasi moral generasi muda yang masih belum bisa menyaring perkembangan globalisasi seperti yang telah dijelaskan pada pembahasan sebelumnya. Tawuran antar pelajar, free sex, narkoba, KKN dan tindakan asusila maupun pelanggaran hukum banyak mewarnai pendidikan Indonesia, bahkan hal ini dapat disaksikan baik secara langsung maupun di media massa yang notabenenya berasal dari kaum terpelajar dan merupakan out put dari lembaga pendidikan. Fenomena yang terjadi menimbulkan pandangan dan pemikiran bahwa pendidikan hanya terjadi pada proses transfer of knowledge tanpa ada kemampuan untuk transformation of knowledge dan internalization of values.

Meskipun di sekolah-sekolah tetap diajarkan, namun hasilnya tidak mampu membentuk sikap atau akhlak peserta didiknya. Di sekolah mereka memang diajarkan tentang nilai, tetapi ketika mereka hidup di lingkungan luar pagar sekolah, justru yang 
mereka temukan berbeda dengan yang mereka pelajari. Seolah-olah lingkungan mereka mengajarkan tetap hidup mesti nafsi-nafsi, cari kekayaan dengan korupsi, bicara harus berapologi, mengembangkan usaha dengan manipulasi dan sebagainya, sehingga kondisi ini akan menghambat, bahkan membunuh potensinya dalam membertuk kepribadian yang berakhlakul karimah. Oleh karenanya, ada anggapan yang cukup ekstrem dari sebagian masyarakat yang menilai rusaknya moral atau akhlak masyarakat terutama masyarakat muslim yang mayoritas di Indonesia, merupakan bukti konkret dari kegagalan pendidikan (Muhammad Kosim, 2012: 128).

Untuk itu, pendidikan Indonesia perlu melakukan reorientasi terhadap tujuan. Disebut reorientasi karena konsep dasar tujuan pendidikan telah jelas, yaitu sebagaimana pandangan terhadap manusia sebagaimana uraian sebelumnya. Manusia dipandang sebagai kesatuan yang utuh, yakni kesatuan jasmani dan rohani, kesatuan makhluk pribadi, sosial dan makhluk tuhan, kesatuan melangsungkan, mempertahankan, dan mengembangkan hidupnya. Dengan pandangan ini, maka tujuan pendidikan akan mengintroduksi terbentuknya manusia dan masyarakat seutuhnya (Ali Maksum dan Luluk Yunan Ruhendi, 2004: 186-87). Namun yang terpenting adalah kebijakan dari penerapan pendidikan dan pelaksanaannya mesti tetap mengacu pada hakikat manusia dan rumusan tujuan pendidikan serta dipandang perlu konsisten dalam penerapannya.

\section{Relevansi Materi}

Ibnu Miskawaih membagi ilmu kepada dua golongan: al-Ulumul Syarifah (ilmuilmu yang mulia) dan al-ulumul radli'ah (ilmu-ilmu yang hina). Martabat suatu ilmu sesuai dengan urutan martabat hakikat objek ilmu itu dalam alam ini, misalnya ilmu tentang manusia lebih mulia dari objek binatang, ilmu binatang lebih mulia dari tumbuh-tumbuhan. Karena itu, dapat dipahami bahwa kecenderungan Ibnu Miskawaih kepada ulumul 'aqliyah, sebagai ilmu yang utama dipelajari karena menunjang tercapainya kualitas manusia yang sempurna. Menurut Abuddin Nata ada perbedaan Imam Al-Ghazali dan Ibnu Miskawaih, Ibnu Miskawaih tidak membeda-bedakan antara materi yang terdapat dalam ilmu agama dan materi yang terdapat dalam ilmu nonagama serta hukum mempelajarinya (Abuddin Nata, 2003: 13).

Materi pendidikan akhlak yang wajib bagi kebutuhan manusia disebutkan olah Ibnu Miskawaih antara lain shalat, puasa, sa'I (Helmi Hidayat, 1994: 123). Ibnu Miskawaih tidak memberi penjelasan lebih lanjut terhadap contoh yang diajukan ini. Hal ini barangkali didasarkan pada perkiraanya, bahwa tanpa uraian terperinci pun orang sudah menangkap maksudnya. Gerakan-gerakan shalat secara teratur yang paling sedikit dilakukan lima kali sehari seperti mengangkat tangan, berdiri, ruku, dan sujud memang memiliki unsur olah tubuh. Shalat sebagai jenis olah tubuh akan dapat lebih dirasakan dan disadari sebagai olah tubuh (gerak badan) jika dilakukan dalam tempo yang agak lama.

Konsep akhlak yang ditawarkan Ibnu Miskawaih yaitu doktrin jalan tengah sebagai dasar keutamaan akhlak, dimana yang menjadi ukuran akal dan syariat. Dimana akal sebagai jalan tengah untuk bisa membedakan tindakan yang baik dan buruk, mana yang harus dilakukan dan yang ditinggalkan. Sedangkan agama merupakan faktor yang meluruskan karakter remaja yang membiasakan mereka untuk melakukan perbuatan baik, sekaligus mempersiapkan diri mereka untuk menerima kearifan, mengupayakan kebajikan, dan mencapai kebahagiaan melalui berpikir dan penalaran yang akurat.

Ibnu Miskawaih membagi ilmu kepada dua golongan, di Indonesia dibagi kepada dua bentuk, yaitu ilmu agama dan ilmu umum. Ilmu agama ialah ilmu yang diwahyukan artinya bersumber dari wahyu. Kategori ilmu agama ini seperti Al-Quran, qira'ah, hafalan qur'an, tafsir, sunnah, sirah nabi, sahabat, ulama, akhlak, tauhid, hadits, 
ushul figh, fiqih, bahasa Qur'an (nahwu, sorrof, dan balaghoh), metafisika Islam, perbandingan agama, dan kebudayaan Islam. Sementara ilmu umum dibagi dalam empat bagian: pertama, pengetahuan imajinatif atau seni (arsitektur Islam, bahasabahasa). Kedua, pengetahuan intelektual meliputi; pengetahuan sosial (kesusanteraan, filsafat, pendidikan, ekonomi, pengetahuan politik, pandangan Islam terhadap politik, ekonomi, kehidupan sosial, perang dan damai, dan lain-lain, kemudian, geografi, sosiologi, linguistik, psikologi, antropologi). Pengetahuan kealaman meliputi; (filsafat sain, matematika, statistika, fisika, kimia, life sciences, astronomi, pengetahuan tentang ruang angkasa, dan lain-lain). Ketiga, rekayasa dan teknologi, kedokteran, pertanian, dan kehutanan. Keempat, pengetahuan praktis; perdagangan, administrasi, perpustakaan, home sciences, komunikasi (Ahmad Tafsir, 2013: 12-16). Konsep ilmu pada pendidikan Indonesia memiliki relevansi dengan pandangan Ibnu Miskawaih yaitu terciptanya manusia agar menjadi filosof (Abuddin Nata, 2003: 15).

Oleh karena itu, pandangan Ibnu Miskawaih tentang ilmu dan klasifikasinya patut dijadikan rujukan untuk pelaksanaan pendidikan karakter di Indonesia. Penggolongan ilmu yang dilakukan oleh Ibnu Miskawaih terfokus kepada jiwa yang menjadikan sumber adanya daya berfikir oleh manusia. Sebab, ilmu yang diperoleh manusia melalui daya berfikir yang keberadaan ilmu tersebut bersumber dari kekuasaan pencipta Allah SWT. Sementara kiat untuk memperoleh keberadaan ilmu itu diserahkan kepada manusia dan bergantung pada kehendak-Nya. Perlu diketahui, untuk memperoleh kesempurnaan manusia dan segenap potensialnya perlu mengejawantahkan potensi tersebut serta berusaha untuk mempertahankannya.

Sementara itu, Imam al-Ghazali memberikan pandangan kepada materi yang bersifat komfrehensif, meliputi seluruh aspek pendidikan. Imam al-Ghazali memberikan pandangan tentang konsep kurikulum pendidikan, bahwa mata pelajaran yang harus di sampaikan kepada peserta didik didasarkan kepada dua pendekatan, yaitu: pertama, Pendekatan Agama seperti Al-Quran dan al-Hadits, ilmu fiqh, ilmu tafsir dan lain sebagainya, kedua Pendekatan Pragmatis seperti ilmu kedoteran, ilmu matematika dan lain sebagainya (Abuddin Nata, 2005: 93).

Klasifikasi ilmu tersebut sepertinya Imam Ghazali ingin mengatakan bahwa pada dasarnya ilmu terbagi kepada dua macam yaitu: pertama, disiplin ilmu yang harus dikuasai oleh setiap individu umat Islam. Ilmu inilah yang masuk dalam katagori fardhu 'ain, karena tidak ada pilihan lain kecuali disiplin ilmu ini harus dimasukan ke dalam kurikulum pendidikan. Kedua, disiplin ilmu yang tidak menuntut kepada setiap individu untuk menguasainya, tetapi cukup diwakili oleh beberapa ummat Islam saja. Disiplin ilmu inilah yang disebut dengan istilah fardhu kifayah. Karenanya jika ada sebagian ummat Islam telah memilikinya maka sudah terwakili.

Adapun konsep materi dalam pendidikan akhlak adalah dengan konsep keseimbangan atau lebih dikenal doktrin jalan tengah. Maksud kekuatan keseimbangan adalah dikendalikannya ambisi dan emosi oleh akal dan syariat. Akal dapat diumpamakan sebagai pemberi nasehat dan arahan. Sedangkan kekuatan keseimbangan adalah sesuatu yang mampu bertindak dan yang melaksanakan apa yang diarahkan atau yang diperintahkan oleh akal. Adapun emosi adalah objek yang padanya perintah tersebutditujukan. Oleh sebab itu, jika sifat keseimbangan (keadilan) telah hilang, tak ada lagi ujung yang berlebihan ataupun yang berkekurangan. Yang ada hanyalah sifak yang sama sekali berlawanan dengannya, yaitu kezaliman.

Dalam pandangan Imam Al-Ghazali ilmu dibagi kepada dua golongan yaitu ilmu yang hukumnya fardhu 'ain dan ilmu yang hukumnya fardhu kifayah. Sedangkan di Indonesia dibagai kepada dua bentuk, yaitu ilmu agama dan ilmu umum. Kedua bentuk 
ilmu ini menjadi bagian dari pendidikan di Indonesia. Secara umum dijelaskan bahwa ilmu agama ialah ilmu yang diwahyukan artinya bersumber dari wahyu. Kategori ilmu agama ini seperti Al-Quran, qira'ah, hafalan qur'an, tafsir, sunnah, sirah nabi, sahabat, ulama, akhlak, tauhid, hadits, ushul fiqh, fiqih, bahasa qur'an (nahwu, sorrof, dan balaghoh), metafisika Islam, perbandingan agama, dan kebudayaan islam (Ahmad Tafsir, 2013: 12-16).

Sementara ilmu-ilmu umum secara garis besar dapat dibagi dalam empat bagian: pertama, pengetahuan imajinatif/seni (arsitektur Islam, bahasa-bahasa). Kedua, pengetahuan intelektual meliputi; pengetahuan sosial (kesusanteraan, filsafat, pendidikan, ekonomi, pengetahuan politik, pandangan Islam terhadap politik, ekonomi, kehidupan sosial, perang dan damai, dan lain-lain, kemudian, geografi, sosiologi, linguistik, psikologi, antropologi). Pengetahuan kealaman meliputi; (filsafat sain, matematika, statistika, fisika, kimia, life sciences, astronomi, pengetahuan tentang ruang angkasa, dan lain-lain). Ketiga, rekayasa dan teknologi, kedokteran, pertanian, dan kehutanan. Keempat, pengetahuan praktis; perdagangan, administrasi, perpustakaan, home sciences, komunikasi.

Dilansir dari sebuah artikel dalam mutudidik. wordpress. com, bahwa salah satu bentuk penguatan pendidikan karakter di Indonesia ialah penguatan pendidikan berbasis kelas, yang terdiri dari:

a. Mengintegrasikan proses pembelajaran di dalam kelas melalui isi kurikulum dalam seluruh mata pelajaran, baik itu secara tematik maupun terintegrasi dalam mata pelajaran.

b. Memperkuat manajemen kelas, pilihan metodologi, dan evaluasi pengajaran.

c. Mengembangkan muatan lokal sesuai dengan kebutuhan daerah.

Penjabaran dari pendidikan karakter berbasis kelas tersebut merupakan suatu penguatan pendidikan karakter di Indonesia. Untuk mencapai hal-hal tersebut, diperlukan rujukan yang tepat. Pandangan Ibnu Miskawaih dan Imam Al-Ghazali tentang ilmu dan klasifikasinya patut dijadikan rujukan dan relevan untuk pelaksanaan pendidikan karakter di Indonesia. Imam Al-Ghazali lebih menitik beratkan pada disiplin ilmu yang wajib dikuasai oleh setiap individu dan disiplin ilmu yang tidak dituntut kepada setiap individu dalam artian sudah terwakili oleh beberapa umat Islam atau orang lain. Imam Al-Ghazali melalui ilmu-ilmu yang dipelajari tersebut mengharapkan tiga unsur yang ada pada manusia berfungsi sesuai dengan potensinya masing-masing. Manusia yang bisa menyelamatkan dirinya dengan amal-amal saleh yang didorong dengan keinginan, mujahadah dan istiqomah dalam mengamalkan ilmunya.

\section{Relevansi Metode Pendidikan}

Dari beberapa metode yang dikemukakan oleh Ibnu Miskawaih diantaranya ada yang relevan dengan pelaksanaan pendidikan di Indonesia. Metode alami masih digunakan dalam pelaksanaan pendidikan di Indonesia. Cara ini berangkat dari pengamatan potensi manusia, dimana potensi yang muncul lebih dahulu, selanjutnya pendidikannya diupayakan sesuai dengan kebutuhan.

Fakta yang terjadi di dunia pendidikan di Indonesia pada jenjang pendidikan yaitu SD/MI, SMP/MTs, SMA/SMK dan MAN masih terdapat jumlah peserta didik 30 sampai 40 yang melebihi kapasiatas kelas. Seharusnya berdasarkan standarisasi pengelolaan pembelajaran di dalam kelas rombel yang diperbolehkan sesuai standar adalah sebanyak $20 \mathrm{~s} / \mathrm{d} 25$ orang per-kelas. Menyikapi persolan tersebut pendidik dipandang kesulitan dalam mengawasi, mengontrol dan mengetahui kerakter peserta didiknya. Oleh karenanya, alangkah lebih baik jika ada penerapan pembelajaran dengan 
memposisikan pendidik sebagai pendamping untuk sejumlah peserta didik. Bahkan lebih baik lagi jika jumlah peserta didik lebih sedikit disetiap kelasnya, misalkan 15 orang, barangkali cara seperti ini sulit diterapkan di Indonesia mengingat pendidik, sarana dan prasarana sekolah yang masih perlu diperhatikan.

Metode bimbingan biasanya digunakan pada pelaksanan Bimbingan Konseling, tetapi dalam pendidikan Islam metode bimbingan juga bisa dilakukan pada materimateri Pendidikan Agama Islam seperti; bimbingan membaca al-Quran, manasik haji, wudu', sholat dan akhlak. Dalam Al-Quran juga menggunakan kalimat-kalimat yang menyentuh hati untuk mengarahkan manusia kepada ide yang dikehendakinya. Inilah yang kemudian dikenal nasihat. Tetapi pada setiap nasihat yang disampaikannya ini selalu dengan teladan dari orang yang memberi nasihat. Ini menunjukkan bahwa antara satu metode yakni nasihat dengan metode lain yang dalam hal ini keteladanan bersifat melengkapi.

Pembiasaan dapat dilakukan sejak anak usia dini dengan sikap dan perilaku yang baik, sopan, santun, menghargai dan menghormati orang lain. Sedangkan untuk pelatihan dan pembiasan dapat diimplementasikan dengan menjalankan ibadah secara bersama dengan keluarga, seperti salat, puasa dan latihan-latihan lainnya. Metode hukuman, hardikan dan pukulan yang ringan merupakan metode terakhir yang digunakan menurut Ibnu Miskawaih. Penerapan metode ini berupa bentuk pemberian ultimatum kepada peserta didik agar mereka tidak lagi berani melakukan keburukan. Di samping itu, metode ini tidak terlepas dari metode-metode lainnya dan tidak dapat dipisahkan.

Metode yang dikemukakan oleh Imam Al-Ghazali diantaranya ada yang relevan dengan pelaksanaan pendidikan di Indonesia. Adapun metode yang beliau tetapkan tersebut adalah metode mujahadah, riyadhah, menyibukkan diri dengan penyucian jiwa, dan peningkatan akhlak (tahzibu al-akhlaq). Metode ini merupakan bagian dari usaha untuk perbaikan akhlak melalui sistim yang dinamakan: Takhalli, Tahalli, dan Tajalli yang dikemukan oleh kaum tasawuf.

Metode ini relevan dengan tujuan Permendikbud No 20 Tahun 2018 pasal 4 ayat 3 tentang muatan karakter dalam penyelenggaraan PPK melalui kurikulum dan pembiasaan pada satuan pendidikan jenjang pendidikan dasar atau satuan pendidikan jenjang pendidikan menengah. Dengan demikian, pendidikan menginginkan melahirkan manusia yang memiliki karakter mulia dengan pembiasaan dan latihanlatihan. Imam al-Ghazali menawarkan metode ini dalam pendidikan akhlak dengan alasan; pertama, beliau adalah ulama yang pemikirannya bercorak tasawuf. Kedua, menjadi manusia yang sempurna sesuai dengan fitrah manusia yaitu beribadah kepada Allah. Ketiga, upaya mencapai hal yang demikian tentunya perlu perbaikan akhlak.

Menurut Ibnu Miskawaih dan Al-Ghazali, untuk mengubah akhlak peserta didik menjadi baik maka dalam pendidikannya diperlukan metode yang terfokus pada dua pendekatan yaitu melalui pembiasaan dan pelatihan, serta peneladanan dan peniruan. Pembiasaan bisa dilakukan sejak usia dini yaitu dengan sikap dan berprilaku yang baik, sopan, dan menghormati orang lain. Sedangkan pelatihan dapat diaplikasikan dengan menjalankan ibadah bersama keluarga seperti salat, puasa, dan latihan-latihan yang lainnya.

Adapun metode yang ditawarkan Imam Al-Ghazali terdapat kesamaan metode dengan yang ditawarkan Ibnu Miskawaih, yaitu pembiasaan, riyadah dan mujahadah. Metode tersebut juga memiliki relevansi dengan pendidikan Indonesia. Sedangkan perbedaan metode Imam Al-Ghazali dengan Ibnu Miskawaih adalah metode anugerah Ilahi dan kesempurnaan fitri. Pengertian metode ini yaitu ketika seorang manusia 
diciptakan dan dilahirkan dalam keadaan memiliki akal sempurna dan perangai yang baik, dengan kekuatan ambisi (syahwat) dan emosi (ghadhab) yang terkendali, sedang, seimbang, dan proporsional, serta bersesuaian dengan akal dan syariat.

Namun demikian, perlunya kolaborasi metode pendidikan akhlak Ibnu Miskawaih dengan Imam Al-Ghazali yang bercorak tasawuf. Dalam hal ini, metode Ibnu Miskawaih seperti metode alami, bimbingan, pembiasaan, dan hukuman, hardikan, serta pukulan yang ringan lebih pada karakter yang bersifat umum. Agaknya penulis lebih cenderung kepada metode yang digunakan oleh Imam Al-Ghazali karena lebih bersifat khusus yaitu metode mujahadah, riyadhah, menyibukkan diri dengan penyucian jiwa, dan peningkatan akhlak (tahzibu al-akhlaq). Bahkan lebih baik lagi, apabila metode Ibnu Miskawaih dan Imam Al-Ghazali dilakukan perpaduan. Sehingga, metode yang digunakan tersebut mendukung peserta didik melakukan perbaikan akhlak ke arah yang lebih, untuk urusan duniawi maupun ukhrawi.

Dalam Penguatan Pendidikan Karakter (PPK) tidak mengubah kurikulum yang sudah ada, melainkan optimalisasi kurikulum pada satuan pendidikan. Pelaksanaan PPK disesuaikan dengan kurikulum pada satuan pendidikan masing-masing dan dapat dilakukan melalui tiga cara, yaitu:

a. Mengintegrasikan pada mata pelajaran yang ada di dalam struktur kurikulum dan mata pelajaran Muatan Lokal (Mulok) melalui kegiatan intrakurikuler dan kokurikuler.

b. Mengimplementasikan PPK melalui kegiatan ekstrakurikuler, yang ditetapkan oleh satuan pendidikan.

c. Kegiatan pembiasaan melalui budaya sekolah dibentuk dalam proses kegiatan rutin, spontan, pengkondisian, dan keteladanan warga sekolah.

Penguatan pendidikan karakter dapat dilaksanakan dengan berbasis struktur kurikulum yang sudah dimiliki oleh sekolah, yaitu pendidikan karakter berbasis kelas, budaya sekolah, dan masyarakat/komunitas. Karena itu dapat dipahami metode atau cara-cara yang digunakan dalam pendidikan karakter memiliki relevansi dengan metode-metode pendidikan yang ditawarkan oleh Ibnu Miskawaih dengan Al-Ghazali, karena metode yang digunakan dalam pendidikan karakter seperti pembiasaan, merupakan metode yang ditawarkan oleh Ibnu Miskawaih. Metode pendidikan menurut Ibnu Miskawaih dan Al-Ghazali dapat dijadikan rujukan untuk metode yang ada di pendidikan karakter. Dengan demikian, metode pendidikan dari Ibnu Miskawaih dan Al-Ghazali, akan membantu pencapaian tujuan dari pendidikan karakter, baik itu yang berbasis kelas, berbasis sekolah, dan berbasis komunitas atau masyarakat.

\section{Relevansi Pendidik dan Peserta Didik}

Ibnu Miskawaih menerangkan bahwa yang menjadi pendidik utama dalam pendidikan akhlak adalah orang tua. Orang tua yang akan mengarahkan anak supaya berperilaku baik, mencintai kebaikan dan berupaya meninggalkan perilaku yang hina. Menurutnya, perlu kerjasama yang intens antara orang tua dengan anak agar kegiatan pendidikan akhlak dapat berjalan lancar. Kegiatan pendidikan akhlak yang dimaksud dengan menanamkan rasa cinta satu sama lainnya.

Konsep pendidik dan peserta didik yang ditawarkan Ibnu Miskawaih tetap relevan untuk dikaji dan dikembangkan dalam meningkatkan pendidikan akhlak atau karakter di Indonesia. Pendidik yang berperan dalam mendidik jiwa peserta didik adalah orang tua untuk mencapai kebahagiaan sejati. Pendidik akan mengajak, merangkul dan mengajarkan peserta didik kebijaksanaan, berperilaku adil, mencintai kebaikan untuk mendapatkan kebahagiaan yang abadi. Adapun yang diharapkan, 
adanya cinta yang tidak memiliki cacat dan terlepas dari pengaruh kematerian, cinta yang dimaksud adalah cinta Ilahi.

Peserta didik harus memiliki kesadaran bahwa ilmu yang dituntut adalah karunia Allah semata, rajin menuntut ilmu, selalu optimis, dan tidak mengandalkan kekuatan berfikir atau logika. Pandangan seperti ini menunjukkan bahwa peserta didik diharapkan tidak hanya cerdas intelektual semata, tetapi cerdas emosional, spiritual, dan yang terpenting cerdas religius sehingga jadilah peserta didik yang saleh, tekun dan kedudukannya memperoleh kebahagiaan yang sempurna lagi hakiki.

Imam Al-Ghazali juga menaruh perhatian kepada kedua aspek pendidikan (pendidik dan peserta didik). Kondisi seseorang dalam hubungan dengan ilmu pengetahuan dapat dibandingkan dengan empat kondisi, yaitu: kondisi belajar dan menuntut ilmu pengetahuan; kondisi mengetahui dngan menyimpan apa yang tlah dipelajari; kondisi merenungkan dan menikmati apa yang telah diketahui; dan kondisi menyebar luaskan dan mengajarkannya kepada orang lain.

Seorang anak adalah amanah di tangan orang tuanya, sebab jiwanya yang suci adalah permata keluarga yang belum dibentuk dan tanpa goresan apapun. Peserta didik siap menerima pengaruh apapun dari orang lain, maka persipan dan pembinaan akhlaknya haruslah dilakukan sedini mungkin. Sejak awal seorang anak harus dihindarkan dari lingkungan yang jelek dan mesti dirawat dan disusui oleh wanita yang baik-baik. Dengan demikian peran seorang ibu sama pentingnya dengan peran bapak dalam pendidikan anak. Ketika anak memulai pendidikan khuttab-nya, orang tua harus lebih berhati-hati lagi dalam memastikan bahwa anak membagi dan menggunakan waktu dengan baik.

Imam Al-Ghazali ada terdapat delapan kewajiban yang harus ada pada seorang pendidik, sementara peserta didik memiliki sepuluh kewajiban yang telah dijelaskan terlebih dahulu. Dengan demikian, dapat diketahui bahwa pandangan Ibnu Miskawaih dan Al-Ghazali tentang pendidik dan peserta didik, dapat menguraikan dan membantu hal-hal yang berkaitan dengan pendidik dan peserta didik yang ada di dalam pendidikan karakter. Jadi, tidak dapat dipungkiri bahwa pendidikan karakter memerlukan pandangan serta gagasan dari Ibnu Miskawaih dan Al-Ghazali mengenai dua aspek pendidikan ini dalam hal mencapai tujuan pendidikan.

\section{Relevansi Lingkungan Pendidikan}

Lingkungan pendidikan dipegang oleh orang yang terdekat dengan peserta didik. Ibnu Miskawaih menjelaskan bahwa yang terdekat dengan peserta didik adalah orang tua. Dengan demikian terdapat relevansi pemikiaran Ibnu Miskawaih tentang lingkungan pendidikan akhlak dengan lingkungan pendidikan Indonesia. Peran keluarga menjadi hal urgen dalam pendidikan akhlak, dimana puncak tanggung jawab pendidikan terletak pada orang tua, ketika pendidikan di keluarga berjalan baik, maka pad tingkat pendidikan berikutnya seperti di sekolah atau madrasah akan menjadi lebih baik. Al-Ghazali berpendapat bahwa hakikat pendidikan adalah proses saling memengaruhi antara fitrah manusia dengan lingkungan yang mengelillinginya.

Pemikiran Ibnu Miskawaih lingkungan pendidikan akhlak berpusat pada lingkungan keluarga dan Imam Al-Ghazali berpusat pada lingkungan keluarga, sekolah dan masyarakat. Konsep lingkungan pendidikan akhlak ini mememiliki relevansi dengan Permendikbud No 20 Tahun 2018 pasal 5 ayat 1 yang menjelaskan PPK pada Satuan Pendidikan Formal diselenggarakan dengan mengoptimalkan fungsi kemitraan tripusat pendidikan yang meliputi: keluarga, sekolah dan masyarakat. 


\section{SIMPULAN}

Setelah mempelajari pemikiran Ibnu Miskwaih dan Imam al-Ghazali dalam kitab Tahzibul Akhlak dan Ihya Ulum Ad-Din, maka diperoleh beberapa kesimpulan, yaitu: Pertama, dari beberapa komponen pendidikan Akhlak, Ibnu Miskwaih dan Imam alGhazali membicarakan beberapa komponen pendidikan Akhlak dalam Tahzibul Akhlak dan Ihya Ulum Ad-Din-nya, yaitu tentang hakikat manusia, tujuan pendidikan akhlak, materi/ilmu, metode, pendidik, peserta didik, lingkungan pendidikan akhlak. Hasil ini menunjukkan bahwa Ibnu Miskwaih dan Imam al-Ghazali pantas disebut sebagai tokoh pendidikan Akhlak dan pemikir yang multikeilmuan.

Kedua, berdasarkan pokok-pokok pikiran di atas, bisa disimpulkan bahwa pemikiran Ibnu Miskwaih dan Imam al-Ghazali memiliki relevansi dengan Penguatan Pendidikan Karakter di Indonesia saat ini. Relevansi tersebut dapat dilihat dari dua hal, pertama, pemikiran Ibnu Miskwaih dan Imam al-Ghazali memiliki relevansi dengan pelaksanaan pendidikan karakter yang telah ada dan sedang dilaksanakan; dan kedua, pemikiran Ibnu Miskwaih dan Imam al-Ghazali akan tetap relevan untuk diaktualisasikan dalam pelaksanaan Penguatan Pendidikan Karakter dewasa ini. Artinya, relevansi dalam bentuk pertama ada kesesuaian antara konsep pendidikan akhlak Ibnu Miskwaih dan Imam al-Ghazali dengan hal-hal yang telah diterapkan di Indonesia. Namun ada pula teorinya yang belum, atau malah tidak, dilaksanakan padahal pemikiran tersebut masih relevan dan diperlukan saat ini, seperti kolaborasi pemikiran Ibnu Miskwaih dan Imam al-Ghazali untuk menemukan komposisi yang tepat dalam pembinaan akhlak dan pengembangan metode merujuk pada metode yang ditawarkan oleh Ibnu Miskwaih dan Imam al-Ghazali. Relevansi bentuk kedua inilah yang harus didiskusikan lebih lanjut untuk ditindaklanjuti dalam rangka pembenahan dan peningkatan kualitas Penguatan Pendidikan Karakter di Indonesia.

Ketiga, peran Penguatan Pendidikan Karakter dalam Permendikbud dan dikuatkan dengan Perpres mesti dipertegas dengan memberi warna bagi praktik keilmuan yang dilakukan. Penguatan Pendidikan Karakter bukan saja mengajarkan ilmu-ilmu syari'at semata, akan tetapi segala ilmu sesungguhnya berasal dari Allah SWT. Konsekuensinya, pengembangan ilmu pengetahuan yang dilakukan lewat lembaga pendidikan mampu mengantarkan manusia kepada kepatuhan dan ketundukan kepada Allah SWT sehingga ilmu yang dihasilkan memberi kontribusi positif terhadap pembentukan masyarakat yang madani dalam ampunan dan ridhaNya.

\section{REFERENSI}

Al-Ghazali, Ihya Ulum Al-Din, Ter. Muhammad al-Baqir, Mengobati Penyakit Hati Membentuk Akhlak Mulia, Bandung : Mizania, 2015

Ihya Ulum Al-Din, Ter. Muhammad Al-Baqir, Mengobati Penyakit Hati Membentuk Akhlak Mulia, Bandung: Mizan, 2015

, Mi'raj al-Salikin, Kairo : Silsilat Al-saqafat al-Islamiyat, 1964

Arifin, M, Perbandingan Pendidikan Islam, Jakarta: PT. Rineka Cipta, 2002

Aziz, Safrudin, Pemikiran Pendidikan Islam, Yogyakarta: Kalimedia,2015

Dahlan, Abdul Aziz, Pemikiran Falsafi Dalam Islam, Padang : IAIN-Press, 1999 
Jalaluddin, Usman Sa'id, Filsafat Pendidikan Islam: Konsep dan Perkembangan Pemikirannya, Jakarta: Raja Grafindo Persada, 1994

Juraini, Metode Khusus Pendidikan Agama, Malang: Rosda Karya, 2001

Kosim Muhammad, Pemikiran Pendidikan Islam Ibnu Kaldun, Jakarta: Rineka Cipta, 2012

Langgulung, Hasan, Falsafah Pendidikan Islam, Jakarta: Bulan Bintang, 1992

Maksum, Ali dan Luluk Yunan Ruhendi, Paradigma Pendidikan Universal di Era Modern dan Post-Modern, Mencari "Visi Baru" atas "Realitas Baru" Pendidikan Kita, Yogyakarta: IRCiSoD, 2004

Miskawaih, Ibnu, Tahdzib al-Akhlak, Beirut : Darul al-Kutub al-Ilmiah, $1329 \mathrm{H}$

Ibnu, Tahdzib al-Akhlak, Ter. Helmi Hidayat, Menuju Kesempurnaan Akhlak, Bandung: Mizan, 1994

Mustafa, A, Filsafat Islam, Bandung: Pustaka Setia, 2007

Mustaqim, Pemikiran Pendidikan Islam: Kajian Tokoh Klasik dan Kontemporer, Yogyakarta: Pustaka Pelajar, 1999

Nata, Abuddin, Pemikiran Para Tokoh Pendidikan Islam, Cet. I, Yogyakarta: Ar-Ruzz Media, 2005

Rahmaniyah, Istighfarotur, Pendidikan Etika, Malang: UIN-Maliki Press, 2010

Rusn, Abidin Ibnu, Pemikiran Al-Gazali Tentang Pendidikan, Pustaka Pelajar, Yogyakarta, 1998

Samani, Muchlas dan Hariyanto, Konsep dan Model Pendidikan Karakter, Bandung: Remaja Rosdakarya, 2013

Suwito, Filsafat Pendidikan Akhlak Ibnu Miskawaih, Yogyakarta : Belukar, 2004

Tafsir, Ahmad, Ilmu Pendidikan Islam, Bandung: PT Remaja Rosda karya Offset, 2013

Tirtarahardja, Umar, Pengantar Pendidikan, Jakarta: PT. Rineka Cipta, 2010

Umar, Bukhari, Ilmu Pendidikan Islam, Jakarta: Amzah, 2010

Zafri, Mustafa, Kunci Memahami Ilmu Tasawuf, Surabaya: PT. Bina Ilmu, 1991.

Zar, Sirajuddin, Filsafat Islam, Filosof dan Falsafatnya, Jakarta: PT. Raja Grafindo Persada, 2007

Zuhairini, Filsafat Pendidikan Islam, Jakarta: PT. Bumi Aksara, 2009

https://mutudidik.wordpress.com/2017/02/28/modul-pelatihan-penguatanpendidikan-karakter 